\title{
EDITORIAL
}

\section{Shifting gear \\ New agendas in the sociological study of religion}

$\mathrm{T}$ He various aCADEmic studies that have the social role of religion as their main area have for quite some time been engaged in two rather different tasks: on the one hand there is research that focuses on religion and the role it plays in different social contexts. On the other hand there are the various attempts to historicise and deconstruct the category 'religion' as part of a certain (mainly European) history. The relationship between the two different approaches to the study of religion/'religion' has mostly been that between an older brother and his somewhat annoying younger sibling: slight irritation or ignorance from the first and critique and frustration about not being heard from the second (see for example Peter Beyer's (2003) discussion of the various 'quotation mark' approaches to religion, from W. C. Smith to Talal Asad).

Consequently, these two different approaches within the area of study have with few exceptions lived rather separate lives, pursuing their own agendas and each engaging in their own discussions. The first, being by far the largest, has engaged in a great variety of topics and discussions such as the decrease, increase, return or persistence of religion (Berger 1999, Casanova 1994, Bruce 2000, de Vries 2008), the transformation of religion (Heelas and Woodhead 2005), new, previously unexplored dimensions or locations of religion (Beckford and Gilliat 1999, Riis and Woodhead 2010, Lee and Bullivant 2012), religion and migration (Baumann 2000, Warburg 2006, Gautier and Martikainen 2013), religion and citizenship (Levey and Modood 2009, Bader 2012) to mention but a few sociologically-oriented works within this enormous body of research. The other strand, in which sociologists of religion are scarcely represented, has rather been engaged in discussions about issues such as the hegemony of discourses on religion and the secular (Asad 2003, Fitzgerald 2000), the role of the category 'religion' in colonial administration (Chidester 1996, Masuzawa 2005), or the political embeddedness of the academic study of religion (Molendijk and Pels 1998, McCutcheon 2003). And not least, some scholars in the latter section have argued for the abandonment of the term all together, due to its entanglement with political agendas and lack of referentiality (Smith 1963, Fitzgerald 2000, see also de Vries 2008 for a discussion of this).

Such a stance on the feasibility of the term religion - one could argue - is bound to be either hardly heard, or actually ignored by scholars devoting their professional lives to investigating exactly this: religion. Academic disciplines tend to have their meaning-providing projects which give direction to the people engaged in them, and they tend to have corresponding narratives that drive and dramatise the scholarly work in specific ways (Johansen 2011). Some aspects of the study of religion have been engaged in projects that are based on sharp separations between religion and science, and between the historical or sociological studies of religion (as appropriately academic) and theology (as more or less a branch of religion) - a project that also aims at cultivating approaches to religion which are not 'Christno-centric', as it were. Others have, as mentioned, rather been occupied with deconstructing such boundaries and pointing towards the work they do as part of a particular Western, secular framework. Such different projects are probably hard to reconcile, but they are fortunately not the only paths to follow.

This special issue is based on papers presented in April 2011 at the Annual Conference of the Sociology of Religion Study Group (SOCREL) of the British Sociological Association (BSA), during a panel discussion entitled 'The sociology of what?' The panel 
elicited a lot of interesting debate, which encouraged us to rework the papers for a wider audience. The resulting articles all in different ways seek to bypass the gap between the study of religion and the study of 'religion' as one of critique and conflict. They aim to probe curiously rather than critically what kind of study emerges if we not only acknowledge the historical and social embeddedness of the category 'religion' in some initial conjuration, but instead place it at the heartland of the scholarly enquiry? And not merely with the aim of critiquing Western hegemonies, or providing counter-discourses targeting other scholars of religion, but as part of a joint endeavour: how to think better and more clearly about social life - a life that includes both religion, however we may define it, and a category that is being used by many different actors to grasp and give shape to the world. What kinds of questions and methods become appropriate for the study of 'religion' then? And what kinds of challenges and predicaments does the sociological study of religion face if we take on the lessons learned from the studies of the category 'religion' about the contingency of our object of study as well as our own role in the ongoing production of a category, which is inscribed on a certain historical, political and epistemological landscape? Are these challenges different from the ones other academic fields have faced regarding their origins and their objects in the aftermath of the wave of 'post-' critiques of the modern, Western ideals of neutral, objective, progressive, universal knowledge - be they poststructuralist, post-modernist, post-foundational, post-colonial or post-secular?

The first article in this special issue, 'Post-secular sociology: modes, possibilities and challenges' by Birgitte Schepelern Johansen, argues that the challenges to some degree are different, and this has to do with the way that both the modern category of 'religion' and the scholarly study of the world under this heading has been intimately entangled in and shaped by exactly such ideals. This entanglement seems to have created a reluctance within some quarters of the sociological study of religion towards embracing the scholarly approaches that most vigorously challenge modern scientific ideals of objectivity, neutrality, and factuality among these the various 'post-approaches to knowledge production, ontology, identity and group formation. Such approaches seem to have gained, if not salience, then at least a more solid footing in some of the neighbouring disciplines from which the sociology of religion usually draws inspiration, such as anthropology, political science and sociology. Also branches within theology have welcomed such challenges as a way of regaining scholarly legitimacy. The article situates and discusses these academic preferences and practices within the framework of a possible shift from secularity to post-secularity, and it probes some of the epistemological shifts that are at stake if we are to take seriously the diagnosis of our times as increasingly post-secular. The article proposes three inter-related conceptions of the post-secular, each with different range and with different consequences for the sociological study of religion.

The SUbSEQuent ARTICLES in different ways seek to implement some of the insights and perspectives gained from the post-structural and deconstructionist fields in the study of religion. The article Approaching religion through linguistics: methodological thoughts on a linguistic analysis of "religion" in political communication' by Stephanie Garling points towards the need to do more empirical research on the different ways the category 'religion' is ascribed meaning and how such meanings structure communications in specific social fields. Taking a point of departure in the field of policy-making with examples taken from the political arena of foreign aid, the article shows how a linguistic analysis of the word-games in which 'religion' as a term is situated, can be used to shed light on premises and assumptions upon which this communication rests. The article further presents a series of appropriate analytical tools for doing this. Drawing on Foucauldian discourse analysis and the linguistic analysis of verbal strategies, topoi and metaphors it puts forward a term-based textual analysis to extrapolate the discursive practices that surround the term 'religion'. The article calls for a reconstruction and (re-)arranging of these practices to open up room for problematising the certainties and rationalities that lie within and are reproduced through these practices, thereby prompting to keep them continuously challenged.

THE THIRD ARTICLE 'Fluid concepts of religion in debates on secularisation' by Katarzyna Zielińska does exactly what the previous article calls for. It focuses on the different ways the category 'religion' is shaped and applied within the process of producing meaning. For its empirical analysis it takes the sociological study of religion itself, and the article shows how the concept 'religion' has been used within the debates of secularisation from the early 1960 s until today. The 
article follows the lines of the theoretical discussion that surround secularisation theory, and then confronts this with empirical data that challenges secularisation theory. Taking these theoretical and empirical debates on secularisation as a case study for the understanding of 'religion' in contemporary sociology of religion it becomes clear how the concept itself is a fluid and therefore always moving concept, serving different purposes in different theoretical settings. Therefore the article offers a view on the variety of different languages that lie behind the seemingly similar concepts and it underlines the necessity for new approaches to focus on the empirical realities that are intertwined with and shaped within these different meanings of 'religion'.

The LAST ARTICLE 'The philosophy of the prodigal son' by Urszula Idziak-Smoczynska asks, finally, the question whether not every post-secular turning in the study of religion will inherit a theological turn. It closes therefore the circle that was opened up with the first article and returns, with a different angle, to the question of the specific entanglements that shape the study of 'religion'. By focussing on the post-modern ideas of Jacques Derrida and his master Gérard Granel the article shows the specifically Christian affirmative character that lies within such ideas. Putting the concept of subjectivity into the centre of analysis rather than the often-discussed (common) roots of knowledge and faith, the article draws attention to a link that has not been looked at very often in post-secular thinking so far. So does deconstructivist thinking and the critique of meta-narratives still carry with it the immanent frame of religion? The article leaves this question unanswered but - like all the articles within this special issue - encourages further research on what the new agendas in the sociological study of religion would mean for the subject and conducted studies that go beyond the brotherly quarrel.

\section{BIRGITTE SCHEPELERN JOHANSEN and STEPHANIE GARLING Guest editors}

\section{References}

Asad, Talal 2003. Formations of the Secular: Christianity - Islam - Modernity. Stanford: Stanford University Press.

Bader, Veit 2012. Post-secularism or liberal-democratic constitutionalism. Erasmus Law Review 5(1): 5-26.

Baumann, Martin 2000. Religion, Integration, Migration. Vietnamesische Buddhisten und tamilsche Hindhus in Deutschland. Marburg: Diagonal.
Beckford, James, and Sophie Gilliat 1999. Religion in Prison: Equal Rites in a Multifaith Society. Cambridge: Cambridge University Press.

Berger, Peter L. (ed.) 1999. The Desecularization of the World: Resurgent Religion and World Politics. Washington: The Ethics and Public Policy Center.

Beyer, Peter 2003. Conceptions of religion: on distinguishing scientific, theological and "official" meanings. Social Compass 50(2): 141-60.

Bruce, Steve 2000. God is Dead: Secularization in the West. Oxford: Blackwell.

Casanova, José 1994. Public Religion in the Modern World. Chicago: Chicago University Press.

Chidester, David 1996. Savage Systems: Colonialism and Comparative Religion in Southern Africa. Charlottesville: University of Virginia Press.

de Vries, Hent (ed.) 2008. Religion: Beyond a Concept. New York: Fordham University Press.

Fitzgerald, Timothy 2000. The Ideology of Religious Studies. New York: Oxford University Press.

Gautier, Francois, and Tuomas Martikainen (eds) 2013. Religion in the Neo-Liberal Age: Political Economy and Modes of Governance. London: Ashgate.

Heelas, Paul, and Linda Woodhead 2005. The Spiritual Revolution: Why Religion is Giving Way to Spirituality. Oxford: Blackwell.

Johansen, Birgitte Schepelern 2011. 'Doing the secular': academic practices in the study of religion at two Danish universities. Arts and Humanities in Higher Education 10(3): 279-93.

Lee, Lois, and Stephen Bullivant 2012. Interdisciplinary studies of non-religion and secularity: the state of the union. Journal of Contemporary Religion 27(1): 19-27.

Levey, Geoffrey B., and Tariq Modood (eds) 2009. Secularism, Religion and Multi-Cultural Citizenship. Cambridge: Cambridge University Press.

Masusawa, Tomoko 2005. The Invention of World Religions: How European Universalism was Preserved in the Language of Pluralism. Chicago: Chicago University Press.

McCutcheon, Russell T. 2003. The Discipline of Religion: Structure, Meaning, Rhetoric. London and New York: Routledge.

Molendijk, Arie L., and Peter Pels (eds) 1998. Religion in the Making: The Emergence of the Science of Religion. Leiden: Brill.

Riis, Ole, and Linda Woodhead 2010. A Sociology of Religious Emotions. Oxford: Oxford University Press.

Smith, Wilfred C. 1963. The Meaning and End of Religion: A New Approach to the Religious Traditions of Mankind. New York: Macmillan.

Warburg, Margit 2006. Citizens of the World: A History and Sociology of the Baha'i from a Globalization Perspective. Leiden: Brill. 